\title{
Attack of molecular iodine to novel palladacyclopentadienyl complexes bearing isocyanides as spectator ligands. A computational and mechanistic study
}

\author{
Luciano Canovese*, Fabiano Visentin, Cladio Santo \\ Dipartimento di Scienze Molecolari e Nanosistemi, Università Ca' Foscari, Calle Larga S. Marta 2137, 30123 Venezia, Italy
}

\section{A R T I C L E I N F O}

\section{Article history:}

Received 22 April 2014

Received in revised form

14 July 2014

Accepted 17 July 2014

Available online 7 August 2014

\section{Keywords:}

Palladacyclopentadienyl complexes

Isocyanides

Iodine addition

Kinetic study

\begin{abstract}
A B S T R A C T
We have synthesized some palladacyclopentadienyl complexes bearing 2,6-dimethylbenzo-, 2tosylaceto- and $t$-butyl-isocyanides (DIC, TOSMIC and TIC, respectively) as spectator ligands. The oxidative addition of $\mathrm{I}_{2}$ to the DIC derivatives yielded complexes bearing iodine, the butadienyl fragment $\sigma$-coordinated, and the isocyanides in mutual trans position as final species. On the basis of a kinetic study carried out by means of UV-vis and ${ }^{1} \mathrm{H}$ NMR techniques we have proposed a plausible mechanism which is in accord with a computational investigation done by other authors on similar compounds and confirmed by a computational approach we have performed. The proposed mechanism suggests the formation of a Pd(IV) octahedral intermediate complex bearing two iodines in meridional position. The latter yields another intermediate complex bearing iodine, the open butadienyl fragment $\sigma$-coordinated, and the isocyanides cis to each other which eventually isomerizes to the final trans product. The reaction rates related to the formation of the cis derivatives $\left(k_{1}\right)$ and to the isomerization process $\left(k_{1}^{\prime}\right)$ were determined as refined parameters of the non linear regression analysis of the monoexponential relationship which is a function of the UV-vis spectral changes and time.
\end{abstract}

(๑) 2014 Elsevier B.V. All rights reserved.

\section{Introduction}

Many natural and bioactive compounds enclose in their structures highly conjugated poly-unsaturated units. Consequently, the stereospecific synthesis of conjugated dienes became an important field of study and several catalytic approaches based on different metals [1] such as the diyne reduction with zinc/copper or sodium/ mercury amalgam [2] and synthetic processes through the metallacyclopentadienyl derivatives of titanium, zirconium, iridium [3] and palladium [4] were proposed.

In particular we have investigated the mechanism of formation of the palladacyclopentadienyl compounds when activated alkynes such as dimethyl-2-butynedioate (dmdb) and methyl(4nitrophenyl)propynoate (pna) attack Palladium(0) alkene complexes bearing bidentate heteroditopic and symmetric spectator ligands [5].

Eventually, addition of halogens $\left(\mathrm{X}_{2}\right)$ or organic halides $(\mathrm{RX})$ to the palladacyclopentadienyl complexes $\mathbf{A}$ induces the formation of the ( $\sigma$-butadienyl) $\operatorname{Pd}(\mathrm{II})$ species $\mathbf{B}$ or $\mathbf{B}^{\prime}$, respectively. Further

\footnotetext{
* Corresponding author. Tel.: +39 041 2348655; fax: +39 0412348517.

E-mail address: cano@unive.it (L. Canovese).
}

addition of halogens liberates the 1,3-dienes unit (C) and the dihalo palladium(II) complex (D), respectively (Scheme 1) [4g]. Alternatively, transmetalation between $\mathbf{B}^{\prime}$ and tin reagents can also yield the unsaturated organic moieties $\mathbf{C}^{\prime}$ and the olefin derivative $\mathbf{E}$ [4d,f].

We have now prepared some new cyclopentadienyl palladium derivatives bearing isocyanides as spectator ligands with the aim of study the propensity of such complexes characterized by the presence of four carbon atoms bound to the metal centre toward the addition of molecular halogens (Scheme 2). Moreover, we hoped to shed light on the reaction mechanism thanks to the retarding effect that the electron-withdrawing isocyanide could have on the rate of the oxidative process. As a matter of fact, in almost all the cases the complexes react immediately and quantitatively with a stoichiometric amount of $I_{2}$ to give the $\sigma$-butadienyl derivative, apart from the case of complex 1a.

Since in this latter case the reaction went to completion in a reasonable time interval, we had the opportunity to carry out a kinetic study which will be described in this paper and was never dealt with at the best of our knowledge. In addition to the starting complexes, in the following Scheme 2 are reported the reaction products and the related numbering scheme. 


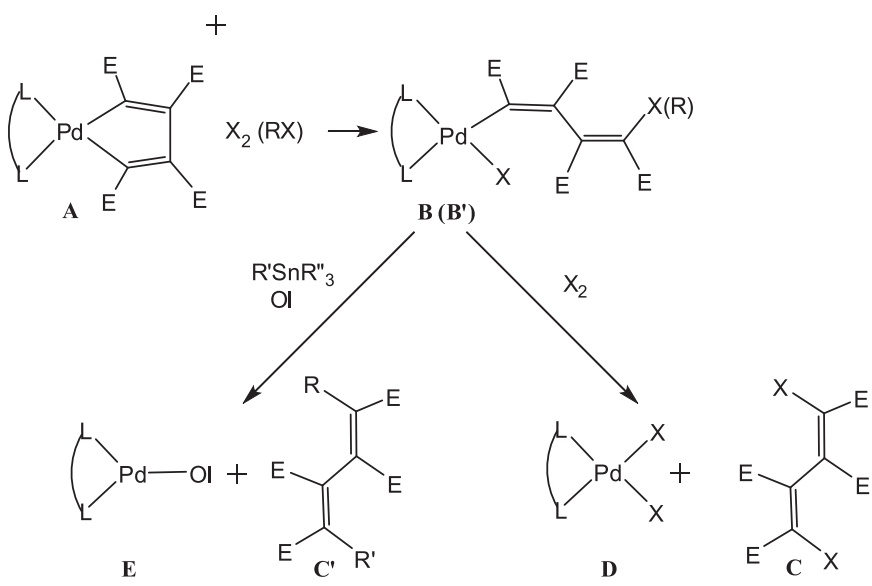

Scheme 1. Synthesis of conjugated dienes from palladacyclopentadienyl complexes.

\section{Result and discussion}

Synthesis of the palladacyclopentadienyl complexes $\left[\mathrm{Pd}(\mathrm{CNR})_{2} \mathrm{C}_{4}\left(\mathrm{COOR}^{\prime}\right)_{4}\right]$

The polymer $\left[\mathrm{PdC}_{4}\left(\mathrm{COOR}^{\prime}\right)_{4}\right]_{n}\left(\mathrm{R}^{\prime}=\mathrm{Me}, t-\mathrm{Bu}\right)$ prepared according to published procedure [4a] reacts in anhydrous acetone under inert atmosphere with a stoichiometric amount of CNR isocyanides yielding the $\mathrm{Pd}(\mathrm{II})$ complexes $\mathbf{1 a}-\mathbf{f}$ as easily separable and stable whitish or yellowish solids. The symmetry of the ensuing complexes $\left(\mathrm{C}_{2 \mathrm{v}}\right)$ induces a remarkable simplification in the ${ }^{1} \mathrm{H}$ and ${ }^{13} \mathrm{C}$ NMR spectra. The two coordinated isocyanides resonate as a unique signal and at a markedly different field from that of the free CNR ligands. Typically, the chemical shift of the isocyanide carbon is in any case found in the range of $134 \div 148 \mathrm{ppm}$ whereas the signals of the COOR fragments in the cyclopentadienyl rings are gathered into two groups as a consequence of their $\alpha$ or $\beta$ position with respect to the palladium centre. Finally, the IR spectra display the expected two bands at ca. $2200 \mathrm{~cm}^{-1}$ due to the $\mathrm{C} \equiv \mathrm{N}$ stretching of two isocyanides cis each other in a square planar derivative $\left(A_{1}+B_{1}\right)$ (see Experimental).

The reaction of a solution of the complexes $\mathbf{1 a}-\mathbf{c}$ in anhydrous $\mathrm{CH}_{2} \mathrm{Cl}_{2}$ with a stoichiometric amount of $\mathrm{I}_{2}$ leads to the formation of the trans isocyanide derivatives of $\mathrm{Pd}(\mathrm{II}) \mathbf{3 a}-\mathbf{c}$. The complexes $\mathbf{3 a}$ and $\mathbf{3 c}$ are fairly stable whereas $\mathbf{3 b}$, although stable as a solid, slowly decomposes in acetone or $\mathrm{CH}_{2} \mathrm{Cl}_{2}$ solution. The characterization carried out by NMR and IR spectroscopy clearly points to the trans distribution of the isocyanides in the ensuing complexes 3 $\left(C_{2 v}\right)$. As a matter of fact, the coordinated isocyanides exhibit only a single signal in the NMR spectra and the IR displays a single band at ca. $2200 \mathrm{~cm}^{-1}$ related to the typical $\nu_{\mathrm{CN}}$ stretching of the square planar trans complexes $\left(\mathrm{B}_{2}\right)$. Accordingly, the COOR fragments give rise to four different signals in both the ${ }^{1} \mathrm{H}$ and ${ }^{13} \mathrm{C}$ NMR spectra resonating at frequencies which are modulated by the position of the carboxylate groups with respect to the palladium centre (see Experimental).

\section{Kinetic investigation}

As already stated all the reactions investigated were almost immediate except for the case of the complex 1a whose reaction progress can be followed either under ${ }^{1} \mathrm{H}$ NMR and UV-vis experimental conditions.

The ${ }^{1} \mathrm{H}$ NMR spectrum recorded immediately after mixing the complex 1a and iodine in approximate equimolecular concentrations $\left([\mathbf{1} \mathbf{a}]_{0} \approx\left[\mathrm{I}_{2}\right]_{0} \approx 1 \times 10^{-2} \mathrm{~mol} \mathrm{dm}{ }^{-3}\right.$ ) shows the formation of a transient species which in ca. $30 \mathrm{~m}$ yields the final product 3a (5th spectrum in Fig. 1).

The nature of the transient complex $\mathbf{2 a}$ can be inferred from the spectrum (2) in Fig. 1. As a matter of fact, four distinct signals of the $\mathrm{OCH}_{3}$ protons are observed in the 3.65-3.85 ppm interval, whereas the methyl substituents of the phenyl group resonate as a couple of signals, one of which probably isochronous with the signal of the methyl substituents of the final trans derivative 3a at $2.56 \mathrm{ppm}$. These NMR features can be traced back to a complex in which the original cyclobutadienyl ring has already assumed its open structure as $\sigma$-coordinated $-\mathrm{C}_{4} \mathrm{I}(\mathrm{COOMe})_{4}$ fragment whereas the two isocyanides are cis to each other.

In order to analyze in detail the observed phenomenon we turned to the UV-vis technique which offers more advantages with respect to NMR in terms of concentration and detection times. In this respect we noticed that at variance with complex 1a which lends itself to a detailed UV-vis investigation complex $\mathbf{1 b}$ is useless due to its unfavourable absorbance change whereas 1c markedly decomposes. Therefore we set up an experiment whose spectrophotometric output is shown in Fig. 2.

As can be seen in Fig. 2 the reaction triggered by addition of iodine to a solution containing an equimolecular amount of complex 1a involves an immediate change in absorbance followed by a slower reaction whose final a spectrum is coincident with that of an equimolecular solution of an authentic sample of complex 3a independently synthesized. Owing to the consistent time interval characterizing the reactions carried out under NMR or UV-vis conditions we surmised that the slow reaction was due to the cis-trans isomerization of intermediate $\mathbf{2 a}$ into $\mathbf{3 a}$. We
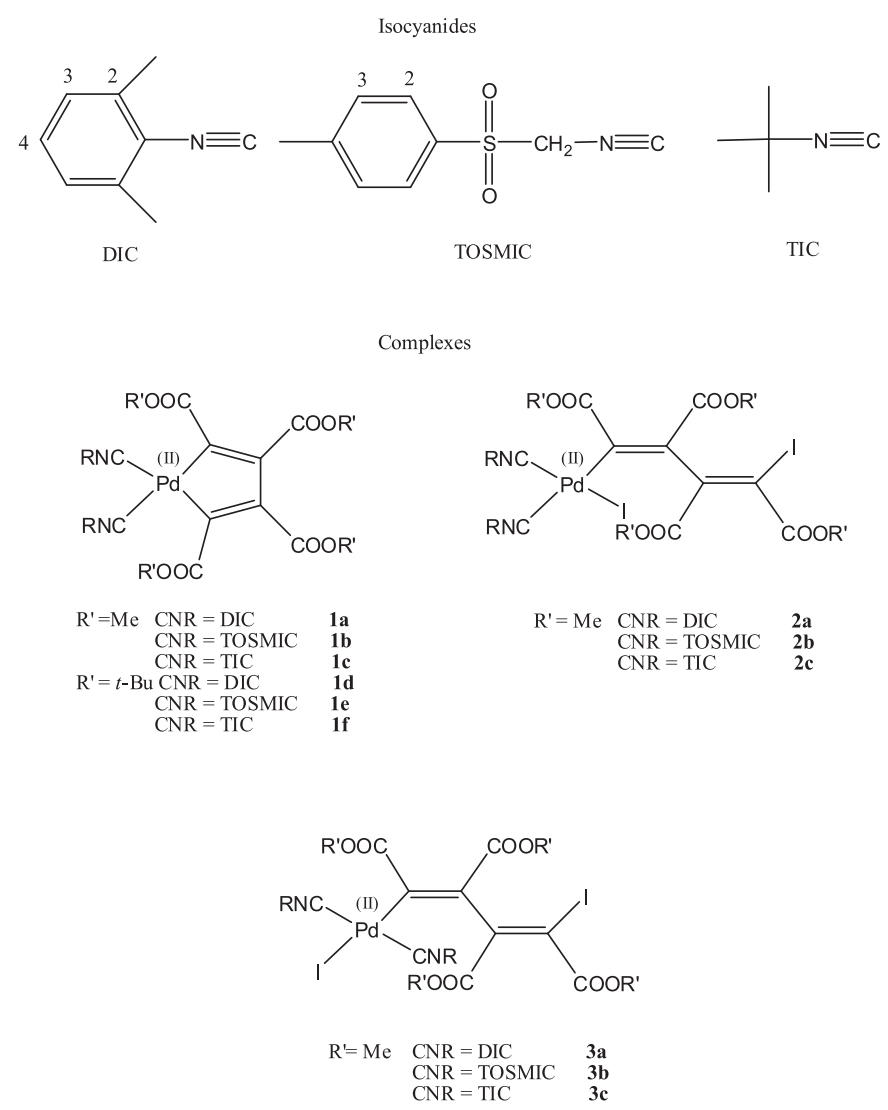

Scheme 2. Starting complexes and reaction products upon $I_{2}$ addition. Type $\mathbf{2}$ complexes are intermediates and not isolated species. 


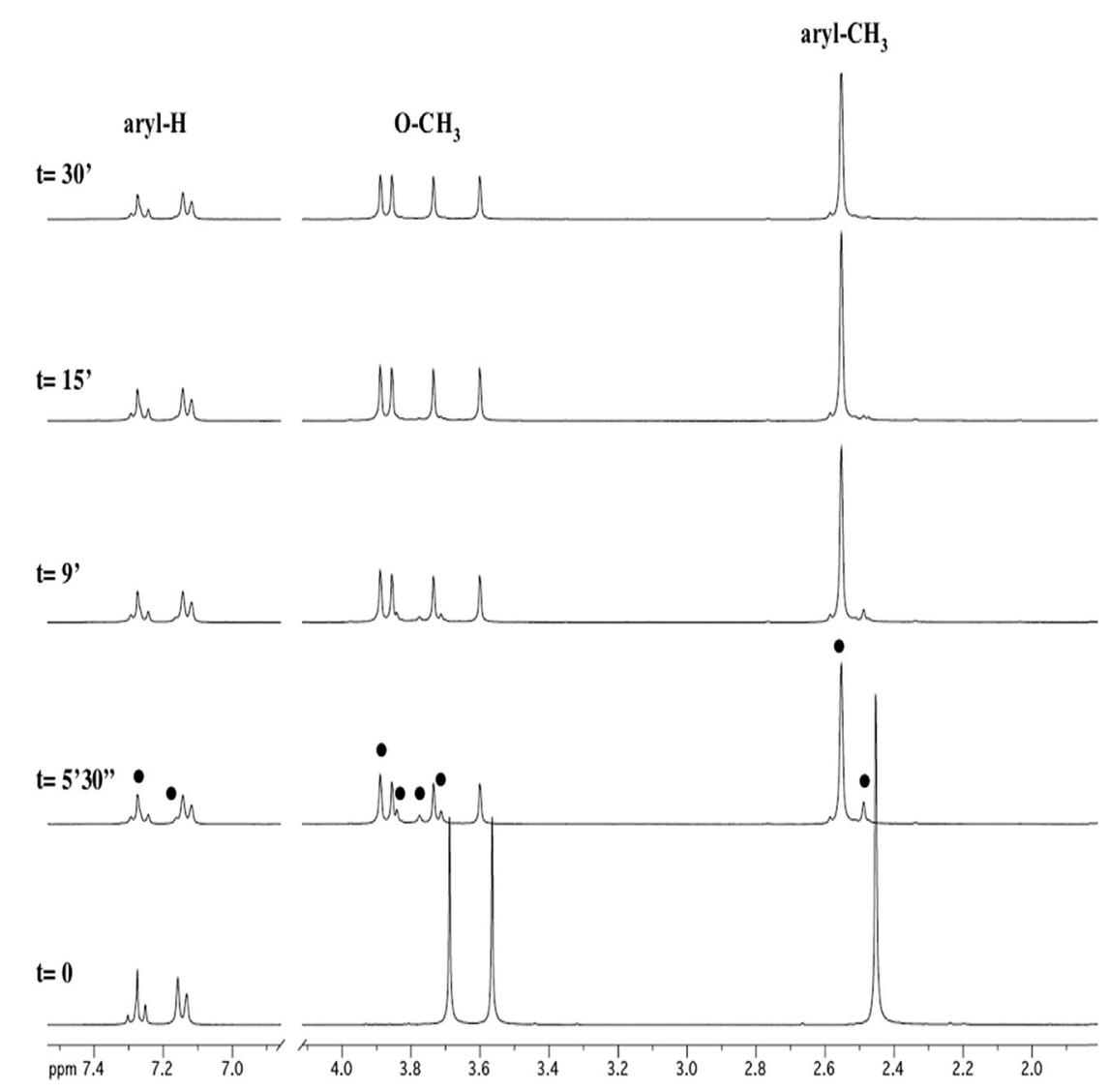

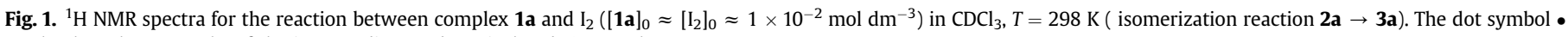
marks the relevant peaks of the intermediate and not isolated cis complex $\mathbf{2 a}$.

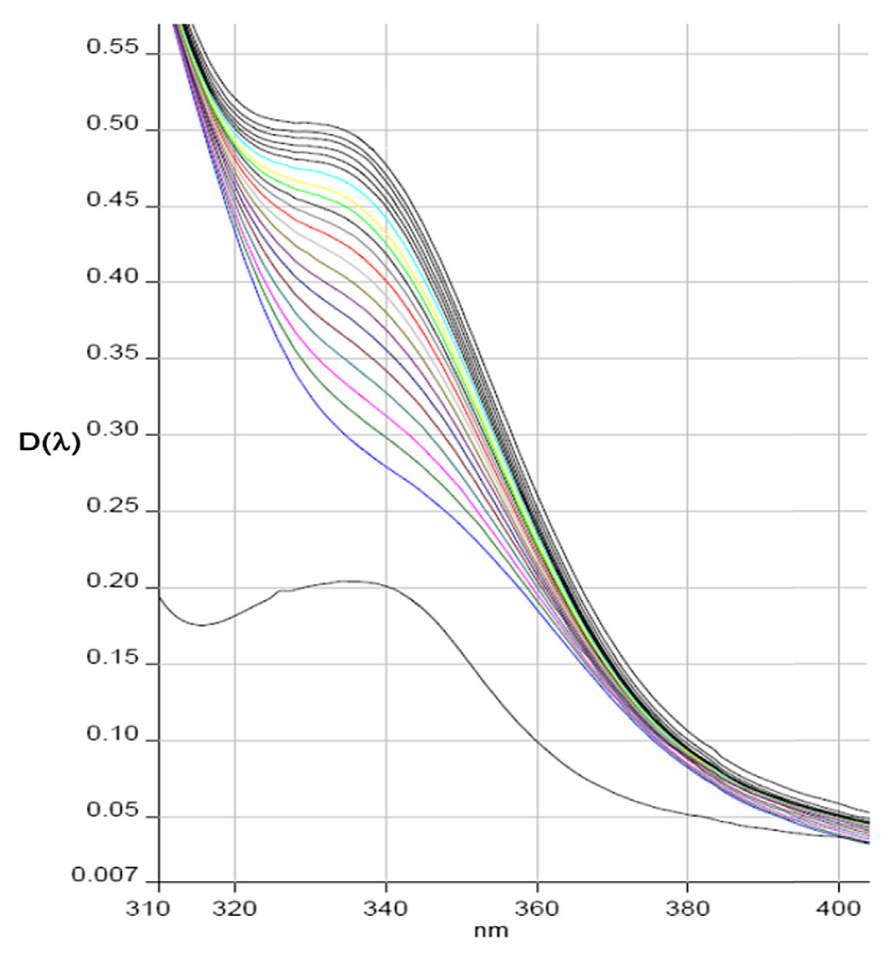

Fig. 2. UV-vis spectra for the reaction between complex $\mathbf{1 a}$ and $\mathrm{I}_{2}$ $\left([\mathbf{1} \mathbf{a}]_{0} \approx\left[\mathrm{I}_{2}\right]_{0} \approx 1 \times 10^{-4} \mathrm{~mol} \mathrm{dm}{ }^{-3}\right)$ in $\mathrm{CHCl}_{3}, T=298 \mathrm{~K}$. hypothesized that the immediate change in absorbance which is apparent in Fig. 2 was due to a rapid process giving quantitatively the intermediate $\mathbf{2 a}$ whereas the subsequent isomerization identified by the change upon time of the halogen $\rightarrow$ Pd LMCT band, was an intramolecular rearrangement yielding the derivative 3a whose reaction rate was independent of the concentration of iodine. The determination of the rate law at different concentrations of $\mathrm{I}_{2}$ confirms the intramolecular nature of the observed process (see Table 1), whereas in Fig. 3 we show a typical reaction profile and the related regression analysis based on the monoexponential function:

$D_{t}-D_{\infty}=\left(D_{0}-D_{\infty}\right) e^{-k 1 t}$

where $D_{t}$ is the time dependent absorbance value, whereas the initial absorbance $D_{0}$, the final $D_{\infty}$ and the monoexponential rate constant $k_{1}$ are the parameters to be optimized by the non linear regression analysis [6].

Table 1

Values of $k_{1}$ determined at different iodine concentrations for the isomerization reaction [7].

$\mathrm{k}_{1}$

$2 \mathbf{a} \rightarrow 3 \mathbf{a}$

\begin{tabular}{ll}
\hline$\left[\mathrm{I}_{2}\right]_{\mathrm{o}}\left(\mathrm{mol} \mathrm{dm}^{-3}\right)$ & $k_{1}\left(\mathrm{~s}^{-1}\right)^{\mathrm{a}}$ \\
\hline $1.0 \times 10^{-3}$ & $(1.29 \pm 0.01) \times 10^{-3}$ \\
$1.5 \times 10^{-3}$ & $(1.26 \pm 0.02) \times 10^{-3}$ \\
$2.0 \times 10^{-3}$ & $(1.36 \pm 0.03) \times 10^{-3}$ \\
\hline
\end{tabular}

${ }^{\text {a }}$ Average value $k_{1}=(1.30 \pm 0.02) \times 10^{-3} \mathrm{~s}^{-1}\left(3 \times t_{1 / 2} \approx 1600 \mathrm{~s}\right)$. 


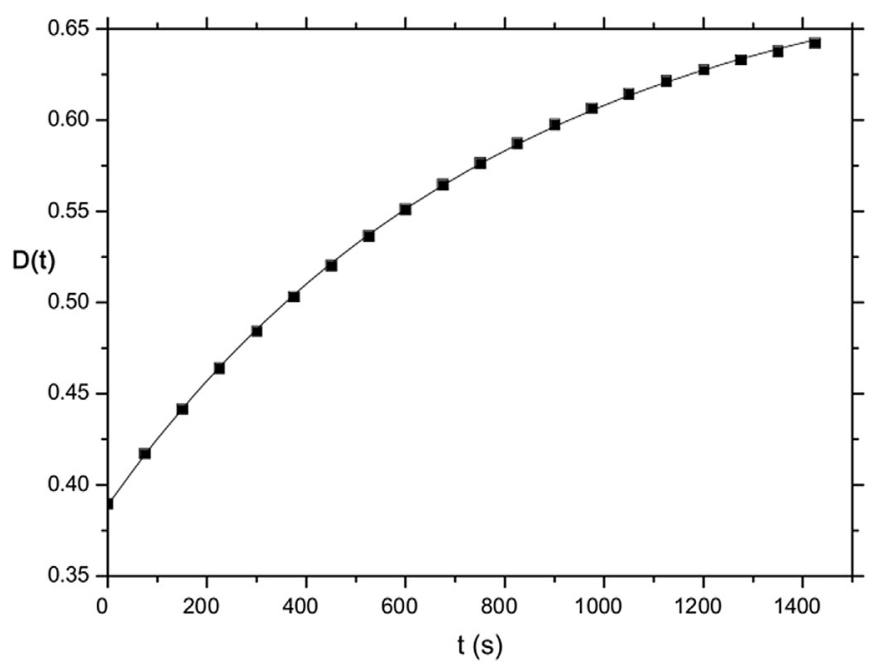

Fig. 3. Absorbance vs. time data and related non linear regression analysis for the isomerisation reaction $\mathbf{2 a} \rightarrow \mathbf{3 a}$ in $\mathrm{CHCl}_{3}$ at $298 \mathrm{~K}$ and $\lambda=340 \mathrm{~nm}\left([\mathbf{2 a}]=1 \times 10^{-4}\right.$, $\left.\left[\mathrm{I}_{2}\right]=1.5 \times 10^{-3} \mathrm{~mol} \mathrm{dm}^{-3}\right)$.

However, an accurate investigation of the initial absorbance change carried out at fixed wavelength $(340 \mathrm{~nm})$ showed that the initial process was better interpreted as a further combination of two reactions, the first of which was immediate, whereas the second took several seconds to be over before the starting of the isomerization process ( $\approx 60 \mathrm{~s}$ ). Furthermore, the spectral change related to the second reaction was not consistent with the global absorbance variation since the $\mathrm{D}_{0}$ value (extrapolated at $t=0$ ) was macroscopically higher than that measured as the sum of the individual absorbances of the starting complex 1a and iodine. At this point we reverted to the determination of the rate of the second reaction by a non-linear regression analysis of the monoexponential function (1) with the same meaning for the symbols previously described.

In Fig. 4 is shown a typical absorbance change and the non linear regression analysis related to the described process.

The rate constant $\left(k_{1}^{\prime}\right)$ which again is independent of the $I_{2}$ concentration, was determined on the basis of three independent experiments carried out at different $\mathrm{I}_{2}$ concentrations and its average value is $(8.6 \pm 0.5) \times 10^{-2} \mathrm{~s}$. At the best of our knowledge this datum, is the first measured rate constant related to the reductive elimination of a halide from a di-halide palladium (IV) complex.

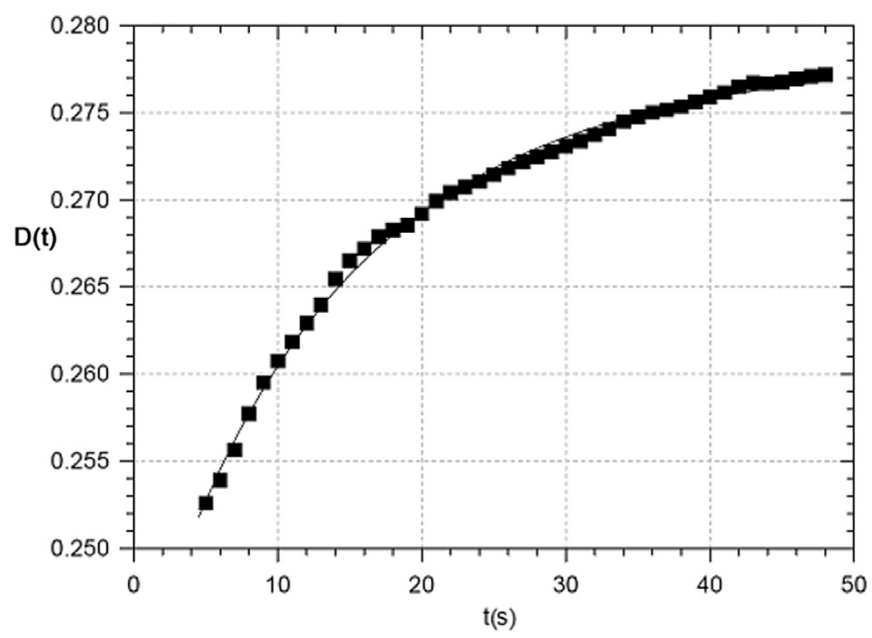

Fig. 4. Absorbance vs. time data and related non linear regression analysis for the reaction involving the reductive iodine migration $\mathbf{I} \rightarrow \mathbf{2 a}$.
On the basis of the described experimental evidence and of the computational study we carried out (vide infra), which is in substantial accord with the reaction scheme proposed by Elsevier and co-workers on the reactivity of palladacyclopentadienes bearing bidentate nitrogen ligands $[4 \mathrm{~g}]$, we infer that the fast but not immediate reaction we observe is related to the process involving the quantitative formation of the intermediate $\mathbf{2 a}$ from the intermediate trans-diiodo Palladium (IV) complex I.

Thus, a representation of the whole process with the observable species involved and the related calculated energies, is shown in the following Scheme 3.

\section{Computational study}

We have carried out a computational study on the substrates and intermediates described in the reaction network of Scheme 3. The free energy values $\left(\Delta G, \mathrm{kcal} \mathrm{mol}^{-1}\right)$ calculated at DFT-PBE0 level [8], are reported together with the optimized structural representations of the involved species in Scheme 4 whereas the whole set of calculated thermodynamic data $(\Delta E, \Delta H, \Delta G)$ is summarized in Table 2. We have chosen the DFT-PBE0 since at present it represents one of the most appropriate levels for the oxidative addition-reductive elimination reactions in palladium complexes [9].

As can be seen in Scheme 4, the first approach of $I_{2}$ to the

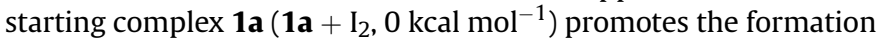
of a van der Waals adduct $\left(-6.7 \mathrm{kcal} \mathrm{mol}^{-1}\right)$ in which $\mathrm{I}_{2}$ is almost perpendicular to the main coordination plane of the complex at the distance of $3.00 \AA$, whereas the I-I bond displays a slight lengthening with respect to the free $\mathrm{I}_{2}$ molecule ( 2.77 vs. $2.68 \AA$ ), indicating a partial charge transfer from iodine to the available orbitals of palladium. The following step gives the octahedral Pd (IV) intermediate $\mathbf{I}\left(-8.6 \mathrm{kcal} \mathrm{mol}^{-1}\right)$ in which both the iodine atoms are bound to palladium centre at an average distance of $2.68 \AA$. The subsequent reaction yielding the intermediate $\mathbf{2 a}$ is characterized by a transition state $\mathbf{T S}\left(+5.0 \mathrm{kcal} \mathrm{mol}^{-1}\right)$ in which an iodine atom migrates from palladium to the carbon atom of the cyclobutadienyl fragment. For the sake of clarity, the bond lengths involved in the process are reported in Table 3 whereas the corresponding activation energy level is at $+13.6 \mathrm{kcal} \mathrm{mol}^{-1}$. The difference in free energy between the intermediate $\mathbf{I}$ and $\mathbf{2 a}$ and between $\mathbf{I}$ and $\mathbf{3 a}$ (-16.8 and $-22.4 \mathrm{kcal} \mathrm{mol}^{-1}$, respectively) matches with the isomerization reaction that is eventually observed.

The schematic representation and the energy data reported above are immediately comparable with those published by Elsevier and Didieu dealing with the oxidative addition of $\mathrm{Br}_{2}$ to palladacyclopentadienyl complexes with bidentate nitrogen species as ancillary ligands $[4 \mathrm{~g}]$. However, the differences among the calculated free energies between the starting complex 1a and the intermediate $\mathbf{I}$ and between the intermediate $\mathbf{I}$ and the transition states TS observed in our case are of reduced extent if compared with those published by Elsevier and Didieu and therefore deserve some comments. Apart from the obvious observation that we are dealing with different systems, it is noteworthy that imposing the same level to the energy of the starting complexes and the related halides yields a $\Delta G$ value for the formation of the intermediate $\mathbf{I}$ which is -8.6 in our and $-15.4 \mathrm{kcal} \mathrm{mol}^{-1}$ in the published case mentioned, respectively. Such a fact can be traced back either to the highest oxidative ability of bromine as compared with that of $\mathrm{I}_{2}$ $\left(E_{\mathrm{Br}_{2} / 2 \mathrm{Br}^{-}}^{0}=1.07 \mathrm{~V} ; E_{\mathrm{I}_{2} / 2 \mathrm{I}^{-}}^{0}=0.54 \mathrm{~V}\right)$ or to the enhanced hardness of $\mathrm{Pd}(\mathrm{IV})$ with respect to $\mathrm{Pd}(\mathrm{II})$ and the consequent increased affinity toward $\mathrm{Br}_{2}$ of the former.

Furthermore, the difference between the calculated $\Delta G$ values between the two transition states is also smaller in our case $(+5$ 
<smiles>CC1=C(F)C(F)=C(F)[Ge]1(C)C</smiles>

1a $\left(0.0 \mathrm{Kcal} \mathrm{mol}^{-1}\right)$<smiles>[18OH][Pb]([18OH])(I)C(F)=C(F)C(F)=C(F)I</smiles>

2a<smiles></smiles>

I (-8.6 Kcal mol $\left.{ }^{-1}\right)$<smiles>C[Ge]([18O])(I)C(F)=C(F)C(F)=C(F)I</smiles>

3a $\left(-31.0 \mathrm{Kcal} \mathrm{mol}^{-1}\right)$

$\mathrm{E}=\mathrm{COOMe}$

Scheme 3. Proposed mechanism for the oxidative addition of $\mathrm{I}_{2}$ to palladacyclopntadienyl complexes with the calculated free energy $\left(\Delta G \mathrm{kcal} \mathrm{mol}^{-1}\right)$ of the species involved. I and $\mathbf{2 a}$ are not isolated intermediate species.

vs. $\left.+8.2 \mathrm{kcal} \mathrm{mol}^{-1}\right)$ although such small differences in energy $\left(\approx 3 \mathrm{kcal} \mathrm{mol}^{-1}\right.$ ) might be traced back to the errors inherent in the computational methods adopted. As for the enhanced stability of complex 2a with respect to the E2 complex of Ref. [4g] ( -25.4 $v s$. $-15.7 \mathrm{kcal} \mathrm{mol}^{-1}$, respectively) it is easily explained by invoking the well known and widely accepted higher affinity of iodide when compared with that of bromide toward the metals of the platinum group [10].

\section{Conclusion}

We have synthesized some novel palladacyclobutadienyl complexes bearing the isocyanides DIC, TOSMIC and TIC as spectator ligands. The reaction of the cis-diisocyanide tetramethyl palladacyclo-1,3-diene-1,2,3,4-tetracarboxylate complexes with iodine yields without exception the trans-diisocyanide-tetramethyl pallada 1-iodobuta-1,3-diene-1,2,3,4-tetracarboxylate. In the favourable case of the DIC derivative (1a) we were able to measure the reaction rate of the intramolecular conversion of the intermediate trans-diiodo Palladium(IV) (I) into the cis-diisocyanide-tetramethyl pallada 1-iodobuta-1,3-diene-1,2,3,4-tetracarboxylate (2a) and the subsequent isomerisation to the trans-isomer (3a). Finally, an adequate computational investigation which is in agreement with previously reported findings appears to support the experimental results we obtained.

\section{Experimental section}

All solvents were purified by standard procedures and distilled under argon immediately before use [11]. 1D- and 2D-NMR spectra

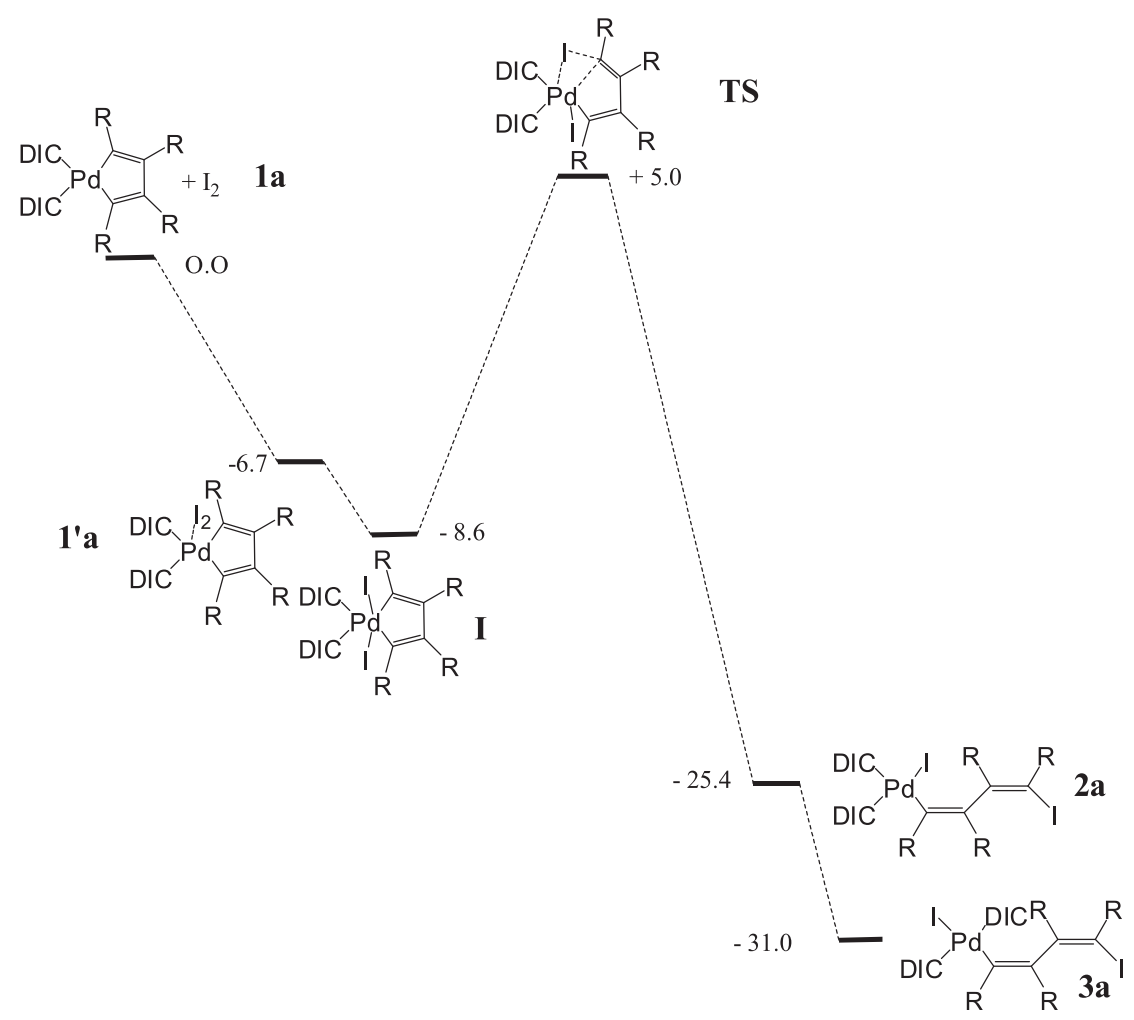

Scheme 4. Calculated free energy $\left(\Delta G \mathrm{kcal} \mathrm{mol}^{-1}\right)$ for the palladium species involved in the reaction of Scheme 3. 
Table 2

Differences in energies $(\Delta E)$, enthalpies $(\Delta H)$ and free energies $(\Delta G)$ in kcal mol ${ }^{-1}$ among reactants, intermediates, transition state and reaction products.

\begin{tabular}{lllllll}
\hline & $\mathbf{1 a}+\mathrm{I}_{2}$ & 1'a & \multicolumn{1}{l}{$\mathbf{I}$} & TS & 2a & 3a \\
\hline$\Delta E$ & 0 & -6.5 & -11.2 & 3.6 & -26.1 & -31.9 \\
$\Delta H$ & 0 & -3.9 & -8.4 & 5.0 & -23.5 & -29.1 \\
$\Delta G$ & 0 & -6.7 & -8.6 & 5.0 & -25.4 & -31.0 \\
\hline
\end{tabular}

were recorded using a Bruker 300 Avance spectrometer. Chemical shifts (ppm) are given relative to TMS $\left({ }^{1} \mathrm{H}\right.$ and ${ }^{13} \mathrm{C}$ NMR).

Peaks are labelled as singlet (s), doublet $(d)$, triplet $(t)$, quartet $(\mathrm{q})$, multiplet $(\mathrm{m})$ and broad (br). The proton and carbon assignment was performed by ${ }^{1} \mathrm{H}-2 \mathrm{D}$ COSY, ${ }^{1} \mathrm{H}-2 \mathrm{D}$ NOESY, ${ }^{1} \mathrm{H}-{ }^{13} \mathrm{C}$ HMQC and $\mathrm{HMBC}$ experiments.

IR spectra were recorded on a Perkin-Elmer Spectrum One spectrophotometer.

UV-vis spectra were obtained on a P.E. Lambda 35 spectrophotometer equipped with a PTP 6 temperature controller Peltier apparatus. The polymeric complexes $\left[\mathrm{PdC}_{4}(\mathrm{COOR})_{4}\right]_{n}(\mathrm{R}=\mathrm{Me}, t-\mathrm{Bu})$ were synthesized according to published methods [4a], whereas the DIC, TOSMIC and TIC isocyanides were commercial grade chemicals and were used without further purification.

\section{Computational details}

Theoretical calculations were performed with the Gaussian 09 [12] package using the functional hybrid GGA PBE0 [8] (PBE1PBE in Gaussian 09 formalism) and the Def2-SVP basis set [13]; solvent effects (dichloromethane, $\varepsilon=8.93$ ) were included using CPCM [14]. The geometry optimization was performed without any symmetry constraint, followed by analytical frequency calculation to confirm that a minimum or a transition state had been reached.

\section{Synthesis of complex 1a}

A mixture of $0.080 \mathrm{~g}(0.205 \mathrm{mmol})$ of the polymeric $\left[\mathrm{PdC}_{4}(\mathrm{COOMe})_{4}\right]_{n}$ and $0.0551 \mathrm{~g}(0.420 \mathrm{mmol})$ of DIC dissolved in $20 \mathrm{ml}$ of anhydrous acetone was stirred for $1 \mathrm{~h}$ under inert atmosphere $(\mathrm{Ar})$. The resulting solution was treated with activated charcoal, filtered on a Celite filter and concentrated to small volume under vacuum. Addition of diethyl ether induced the precipitation of the title complex as a pale yellow microcrystalline solid which was filtered off in a gooch and dried under vacuum at RT to give $0.0823 \mathrm{~g}$ (yield $61 \%$ ) of the complex $\mathbf{1 a}$.

${ }^{1} \mathrm{H} \mathrm{NMR}\left(\mathrm{CDCl}_{3}, \mathrm{~T}=298 \mathrm{~K}, \mathrm{ppm}\right) \delta: 2.46\left(\mathrm{~s}, 6 \mathrm{H}, \operatorname{aryl}-\mathrm{CH}_{3}\right), 3.57(\mathrm{~s}$, $\left.6 \mathrm{H}, \mathrm{OCH}_{3}\right), 3.69\left(\mathrm{~s}, 6 \mathrm{H}, \mathrm{OCH}_{3}\right), 7.15(\mathrm{~d}, J=7.6 \mathrm{~Hz} 4 \mathrm{H}$, aryl m-H), 7.28 ( $\mathrm{t}, J=7.6 \mathrm{~Hz}, 2 \mathrm{H}$, aryl p-H).

${ }^{13} \mathrm{C}\left\{{ }^{1} \mathrm{H}\right\}$ NMR $\left(\mathrm{CDCl}_{3}, \mathrm{ppm}\right) \delta: 18.5\left(\mathrm{CH}_{3}, \mathrm{Ar}-\mathrm{CH}_{3}\right), 51.1\left(\mathrm{CH}_{3}\right.$, $\left.\mathrm{OCH}_{3}\right), 51.4\left(\mathrm{CH}_{3}, \mathrm{OCH}_{3}\right), 128.1(\mathrm{CH}$, aryl $\mathrm{m}-\mathrm{C}), 130.1(\mathrm{CH}$, aryl $\mathrm{p}-\mathrm{C})$, 135.5 (C, aryl o-C), $147.8(\mathrm{C}, \mathrm{CN}), 147.9(\mathrm{C}, \mathrm{C}=\mathrm{C}), 164.2(\mathrm{C}, \mathrm{C}=\mathrm{C})$, 164.2 (C, CO), 174.0 (C, CO).

IR ( $\mathrm{KBr}$ pellets, $\left.\mathrm{cm}^{-1}\right): \nu_{\mathrm{C}-\mathrm{O}} 1207, \nu_{\mathrm{C}}={ }_{\mathrm{O}} 1706, \nu_{\mathrm{C}} \equiv_{\mathrm{N}} 2183-2193$.

Anal. Calc. for: $\mathrm{C}_{30} \mathrm{H}_{30} \mathrm{~N}_{2} \mathrm{O}_{8} \mathrm{Pd}$ : C, 55.18; $\mathrm{H}, 4.63 ; \mathrm{N}, 4.29$. Found: $\mathrm{C}$, 55.31; H, 4.78; N,4.13 (\%).

Table 3

Calculated lengths $(\AA)$ of the involved bonds among intermediate I, TS and complex 2a.

\begin{tabular}{llll}
\hline & I & TS & 2a \\
\hline Pd-I & 2.68 & 2.95 & \\
Pd-C & 2.04 & 2.27 & \\
I-C & 3.26 & 2.23 & 2.10 \\
\hline
\end{tabular}

\section{Synthesis of complex $\mathbf{1 b}$}

The title complex was synthesized following the same procedure as complex 1a using the appropriate isocyanide (TOSMIC). The reaction time was however reduced $(20 \mathrm{~m})$ owing to the propensity of $\mathbf{1 b}$ to decompose.

Whitish microcrystals. Yield 70\%.

${ }^{1} \mathrm{H} \mathrm{NMR}\left(\mathrm{CDCl}_{3}, T=298 \mathrm{~K}, \mathrm{ppm}\right) \delta: 2.50\left(\mathrm{~s}, 6 \mathrm{H}\right.$, aryl $\left.-\mathrm{CH}_{3}\right), 3.57$ $\left(\mathrm{s}, 6 \mathrm{H}, \mathrm{OCH}_{3}\right), 3.64\left(\mathrm{~s}, 6 \mathrm{H}, \mathrm{OCH}_{3}\right), 4.98\left(\mathrm{~s}, 4 \mathrm{H}, \mathrm{CH}_{2} \mathrm{SO}_{2}\right), 7.46(\mathrm{~d}$, $J=8.1 \mathrm{~Hz}$, aryl $\left.\mathrm{H}^{3}\right), 7.85\left(\mathrm{~d}, J=8.1 \mathrm{~Hz}\right.$, aryl $\left.\mathrm{H}^{2}\right)$.

${ }^{13} \mathrm{C}\left\{{ }^{1} \mathrm{H}\right\}$ NMR $\left(\mathrm{CDCl}_{3}, T=298 \mathrm{~K}, \mathrm{ppm}\right) \delta: 21.8\left(\mathrm{CH}_{3}, \operatorname{aryl}-\mathrm{CH}_{3}\right)$, $51.4\left(\mathrm{CH}_{3}, \mathrm{OCH}_{3}\right), 51.5\left(\mathrm{CH}_{3}, \mathrm{OCH}_{3}\right), 62.7\left(\mathrm{CH}_{2}, \mathrm{CH}_{2} \mathrm{SO}_{2}\right), 129.1(\mathrm{CH}$, aryl $\left.\mathrm{C}^{3}\right) ; 130.5\left(\mathrm{CH}\right.$, aryl $\left.\mathrm{C}^{2}\right) ; 132.4\left(\mathrm{C}\right.$, aryl $\left.\mathrm{C}^{1}\right) ; 144.1(\mathrm{C}, \mathrm{CN}) ; 147.0$ $\left(\mathrm{C}\right.$, aryl $\left.\mathrm{C}^{4}\right) ; 148.6(\mathrm{C}, \mathrm{C}=\mathrm{C}), 164.5(\mathrm{C}, \mathrm{C}=\mathrm{C}), 164.6(\mathrm{C}, \mathrm{CO}), 174.4(\mathrm{C}$, $\mathrm{CO})$.

IR (KBr pellets, $\left.\mathrm{cm}^{-1}\right): \nu_{\mathrm{C}-\mathrm{O}} 1155, \nu_{\mathrm{C}}={ }_{\mathrm{O}} 1697, \nu_{\mathrm{C}} \equiv_{\mathrm{N}} 2216-2231$.

Anal. Calc. for: $\mathrm{C}_{30} \mathrm{H}_{30} \mathrm{~N}_{2} \mathrm{O}_{12} \mathrm{PdS}_{2}$ : C, 46.13; H, 3.87; N, 3.59. Found: $\mathrm{C}, 46.41 ; \mathrm{H}, 3.97 ; \mathrm{N}, 3.45 \%$.

\section{Synthesis of complex 1c}

The title complex was synthesized following a similar procedure as complex 1a using the appropriate isocyanide (TIC). The evaporation of acetone was however complete and the resulting solid material was dissolved in diethyl ether and eventually precipitated with hexane.

Whitish microcrystals. Yield $84 \%$.

${ }^{1} \mathrm{H}$ NMR $\left(\mathrm{CDCl}_{3}, T=298 \mathrm{~K}, \mathrm{ppm}\right) \delta: 1.54\left(\mathrm{~s}, 18 \mathrm{H}, \mathrm{NC}\left(\mathrm{CH}_{3}\right)_{3}\right), 3.66$ $\left(\mathrm{s}, 6 \mathrm{H}, \mathrm{OCH}_{3}\right), 3.71\left(\mathrm{~s}, 6 \mathrm{H}, \mathrm{OCH}_{3}\right)$.

${ }^{13} \mathrm{C}\left\{{ }^{1} \mathrm{H}\right\}$ NMR $\left(\mathrm{CDCl}_{3}, T=298 \mathrm{~K} \mathrm{ppm}\right) \delta: 30.0\left(\mathrm{CH}_{3}, \mathrm{NC}\left(\mathrm{CH}_{3}\right)_{3}\right)$, $51.0\left(\mathrm{CH}_{3}, \mathrm{OCH}_{3}\right), 51.2\left(\mathrm{CH}_{3}, \mathrm{OCH}_{3}\right), 57.7\left(\mathrm{C}, \mathrm{NC}\left(\mathrm{CH}_{3}\right)_{3}\right), 134.7(\mathrm{C}, \mathrm{CN})$, 147.4 (C, C=C), 164.0 (C, C=C), 164.2 (C, CO), 174.1 (C, CO).

IR (KBr pellets, $\left.\mathrm{cm}^{-1}\right): \nu_{\mathrm{C}-\mathrm{O}} 1213, \nu_{\mathrm{C}}={ }_{\mathrm{O}} 1712, \nu_{\mathrm{C}} \equiv_{\mathrm{N}} 2202-2218$.

Anal. Calc. for: $\mathrm{C}_{22} \mathrm{H}_{30} \mathrm{~N}_{2} \mathrm{O}_{8} \mathrm{Pd}$ : C, 47.45; H, 5.43; N, 5.03. Found: C, $47.33 ; \mathrm{H}, 5.68 ; \mathrm{N}, 4.87 \%$.

\section{Synthesis of complex 1d}

The title complex was synthesized following a similar procedure as complex 1c using the appropriate isocyanide (DIC), the polymeric palladium complex $\left(\left[\mathrm{PdC}_{4}(\mathrm{COOt}-\mathrm{Bu})_{4}\right]_{n}\right)$ and $30 \mathrm{~m}$ as reaction time.

Whitish microcrystals. Yield $48 \%$.

${ }^{1} \mathrm{H}$ NMR $\left(\mathrm{CD}_{2} \mathrm{Cl}_{2}, T=298 \mathrm{~K}, \mathrm{ppm}\right) \delta: 1.33\left(\mathrm{~s}, 18 \mathrm{H}, \mathrm{C}\left(\mathrm{CH}_{3}\right)_{3}\right), 1.50$ (s, $\left.18 \mathrm{H}, \mathrm{C}\left(\mathrm{CH}_{3}\right)_{3}\right), 2.49\left(\mathrm{~s}, 6 \mathrm{H}\right.$, aryl- $\left.\mathrm{CH}_{3}\right), 7.17(\mathrm{~d}, J=7.6 \mathrm{~Hz}, 4 \mathrm{H}$, aryl m$\mathrm{H}), 7.29(\mathrm{t}, J=7.6 \mathrm{~Hz}, 2 \mathrm{H}$, aryl $\mathrm{p}-\mathrm{H})$.

${ }^{13} \mathrm{C}\left\{{ }^{1} \mathrm{H}\right\}$ NMR $\left(\mathrm{CD}_{2} \mathrm{Cl}_{2}, \mathrm{ppm}\right) \delta: 18.4\left(\mathrm{CH}_{3}, \mathrm{Ar}-\mathrm{CH}_{3}\right), 27.8\left(\mathrm{CH}_{3}\right.$, $\left.\mathrm{C}\left(\mathrm{CH}_{3}\right)_{3}\right), 27.9\left(\mathrm{CH}_{3}, \mathrm{C}\left(\mathrm{CH}_{3}\right)_{3}\right), 79.2\left(\mathrm{C}, \mathrm{C}\left(\mathrm{CH}_{3}\right)_{3}\right), 80.1\left(\mathrm{C}, \mathrm{C}\left(\mathrm{CH}_{3}\right)_{3}\right)$, 125.8 (C, aryl i-C), $125.8(\mathrm{CH}$, aryl $\mathrm{m}-\mathrm{C}), 129.9(\mathrm{CH}$, aryl p-C), $135.6(\mathrm{C}$, aryl o-C), $147.1(\mathrm{C}, \mathrm{C}=\mathrm{C}), 147.9(\mathrm{C}, \mathrm{CN}), 163.2(\mathrm{C}, \mathrm{CO}), 164.1(\mathrm{C}, \mathrm{C}=\mathrm{C})$, 172.9 (C, CO).

IR (KBr pellets, $\left.\mathrm{cm}^{-1}\right): \nu_{\mathrm{C}-\mathrm{O}} 1149, \nu_{\mathrm{C}}={ }_{\mathrm{O}} 1698, \nu_{\mathrm{C}} \equiv_{\mathrm{N}} 2173-2188$.

Anal. Calc. for: $\mathrm{C}_{42} \mathrm{H}_{54} \mathrm{~N}_{2} \mathrm{O}_{8} \mathrm{Pd}$ : C, 61.42; H, 6.63; N, 3.41. Found: C, 61.69; H, 6.78; N, 3.12\%.

\section{Synthesis of complex $1 \boldsymbol{e}$}

The title complex was synthesized following a similar procedure as complex 1d using the appropriate isocyanide (TOSMIC).

Pale yellow microcrystals. Yield $48 \%$.

${ }^{1} \mathrm{H} \mathrm{NMR}\left(\mathrm{CDCl}_{3}, T=298 \mathrm{~K}, \mathrm{ppm}\right) \delta: 1.33\left(\mathrm{~s}, 18 \mathrm{H}, \mathrm{C}\left(\mathrm{CH}_{3}\right)_{3}\right), 1.45(\mathrm{~s}$, $\left.18 \mathrm{H}, \mathrm{OC}\left(\mathrm{CH}_{3}\right)_{3}\right), 2.51\left(\mathrm{~s}, 6 \mathrm{H}\right.$, aryl- $\left.\mathrm{CH}_{3}\right), 4.87\left(\mathrm{~s}, 4 \mathrm{H}, \mathrm{CH}_{2} \mathrm{SO}_{2}\right), 7.51(\mathrm{~d}$, $J=8.3 \mathrm{~Hz}$, aryl H3), $7.91\left(\mathrm{~d}, J=8.3 \mathrm{~Hz}\right.$, aryl $\left.\mathrm{H}^{2}\right)$.

${ }^{13} \mathrm{C}\left\{{ }^{1} \mathrm{H}\right\}$ NMR $\left(\mathrm{CDCl}_{3}, T=298 \mathrm{~K}, \mathrm{ppm}\right) \delta: 21.8\left(\mathrm{CH}_{3}\right.$, aryl $\left.-\mathrm{CH}_{3}\right)$, $28.0\left(\mathrm{CH}_{3}, \mathrm{OC}\left(\mathrm{CH}_{3}\right)_{3}\right), 28.2\left(\mathrm{CH}_{3}, \mathrm{OC}\left(\mathrm{CH}_{3}\right)_{3}\right), 62.7\left(\mathrm{CH}_{2}, \mathrm{CH}_{2} \mathrm{SO}_{2}\right), 79.3$ 
$\left(\mathrm{C}, \mathrm{OC}\left(\mathrm{CH}_{3}\right)_{3}\right), 80.4\left(\mathrm{C}, \mathrm{OC}\left(\mathrm{CH}_{3}\right)_{3}\right), 129.2\left(\mathrm{CH}\right.$, aryl $\left.\mathrm{C}^{2}\right) ; 130.8(\mathrm{CH}$, aryl $\left.\mathrm{C}^{3}\right) ; 132.0\left(\mathrm{C}, \operatorname{aryl} \mathrm{C}^{1}\right) ; 146.5(\mathrm{C}, \mathrm{CN}) ; 147.3\left(\mathrm{C}\right.$, aryl $\left.\mathrm{C}^{4}\right) ; 148.0(\mathrm{C}, \mathrm{C}=$ C), 163.2 (C, CO), 163.3 (C, C=C), 172.9 (C, CO).

IR $\left(\mathrm{KBr}\right.$ pellets, $\left.\mathrm{cm}^{-1}\right): \nu_{\mathrm{C}-\mathrm{O}} 1155, \nu_{\mathrm{C}}={ }_{\mathrm{O}} 1703, \nu_{\mathrm{C}} \equiv_{\mathrm{N}} 2202-2219$.

Anal. Calc. for: $\mathrm{C}_{42} \mathrm{H}_{54} \mathrm{~N}_{2} \mathrm{O}_{12} \mathrm{PdS}_{2}$ : C, 53.13; H, 5.73; N, 2.95 . Found: C, 53.21; H, 5.87; N, 2.93\%.

\section{Synthesis of complex $\mathbf{1 f}$}

The title complex was synthesized following a similar procedure as complex 1c using the appropriate isocyanide (TIC) and $10 \mathrm{~m}$ as reaction time.

Pale yellow microcrystals. Yield $84 \%$.

${ }^{1} \mathrm{H}$ NMR $\left(\mathrm{CDCl}_{3}, T=298 \mathrm{~K}, \mathrm{ppm}\right) \delta: 1.47\left(\mathrm{~s}, 18 \mathrm{H}, \mathrm{OC}\left(\mathrm{CH}_{3}\right)_{3}\right), 1.49$ $\left(\mathrm{s}, 18 \mathrm{H}, \mathrm{OC}\left(\mathrm{CH}_{3}\right)_{3}\right), 1.52\left(\mathrm{~s}, 18 \mathrm{H}, \mathrm{NC}\left(\mathrm{CH}_{3}\right)_{3}\right)$.

${ }^{13} \mathrm{C}\left\{{ }^{1} \mathrm{H}\right\}$ NMR $\left(\mathrm{CDCl}_{3}, \mathrm{ppm}\right) \delta: 28.3\left(\mathrm{CH}_{3}, \mathrm{OC}\left(\mathrm{CH}_{3}\right)_{3}\right), 28.4\left(\mathrm{CH}_{3}\right.$, $\left.\mathrm{OC}\left(\mathrm{CH}_{3}\right)_{3}\right), 30.1\left(\mathrm{CH}_{3}, \mathrm{NC}\left(\mathrm{CH}_{3}\right)_{3}\right), 57.5\left(\mathrm{C}, \mathrm{NC}\left(\mathrm{CH}_{3}\right)_{3}\right), 78.8$ (C, $\left.\mathrm{OC}\left(\mathrm{CH}_{3}\right)_{3}\right), 79.7\left(\mathrm{C}, \mathrm{OC}\left(\mathrm{CH}_{3}\right)_{3}\right), 136.1(\mathrm{C}, \mathrm{CN}), 147.6(\mathrm{C}, \mathrm{C}=\mathrm{C}), 163.5(\mathrm{C}$, $\mathrm{CO}), 163.8(\mathrm{C}, \mathrm{C}=\mathrm{C}), 173.3$ (C, CO).

IR $\left(\mathrm{KBr}\right.$ pellets, $\left.\mathrm{cm}^{-1}\right): \nu_{\mathrm{C}-\mathrm{O}} 1152, \nu_{\mathrm{C}}={ }_{\mathrm{O}} 1701, \nu_{\mathrm{C}} \equiv_{\mathrm{N}} 2195-2209$.

Anal. Calc. for: $\mathrm{C}_{34} \mathrm{H}_{54} \mathrm{~N}_{2} \mathrm{O}_{8} \mathrm{Pd}$ : C, $56.31 ; \mathrm{H}, 7.51$; N, 3.86. Found: C, 56.05; H, 7.65; N, 3.71\%.

\section{Synthesis of complex $\mathbf{3 a}$}

To a solution of $0.05 \mathrm{~g}(0.77 \mathrm{mmol})$ of complex $\mathbf{1 a}$ in $15 \mathrm{ml}$ of freshly distilled anhydrous $\mathrm{CH}_{2} \mathrm{Cl}_{2}(\mathrm{Ar}) \mathrm{a} \mathrm{CH}_{2} \mathrm{Cl}_{2}$ solution containing $0.0395 \mathrm{~g}(0.156 \mathrm{mmol})$ of $\mathrm{I}_{2}$ was added under inert atmosphere. The mixture was stirred for $5 \mathrm{~m}$ and then reduced to small volume under vacuum at RT. Upon addition of diethyl ether the title complex precipitated as an orange solid which was filtered off in a gooch and dried under vacuum to give $0.0586 \mathrm{~g}$ (yield $84 \%$ ) of final product.

${ }^{1} \mathrm{H} \mathrm{NMR}\left(\mathrm{CDCl}_{3}, T=298 \mathrm{~K}, \mathrm{ppm}\right) \delta: 2.56\left(\mathrm{~s}, 6 \mathrm{H}\right.$, aryl $\left.-\mathrm{CH}_{3}\right), 3.60(\mathrm{~s}$, $\left.3 \mathrm{H}, \mathrm{OCH}_{3}\right), 3.74\left(\mathrm{~s}, 3 \mathrm{H}, \mathrm{OCH}_{3}\right), 3.85\left(\mathrm{~s}, 3 \mathrm{H}, \mathrm{OCH}_{3}\right), 3.89\left(\mathrm{~s}, 3 \mathrm{H}, \mathrm{OCH}_{3}\right)$, $7.13(\mathrm{~d}, J=7.6 \mathrm{~Hz} 4 \mathrm{H}$, aryl $\mathrm{m}-\mathrm{H}), 7.28(\mathrm{t}, J=7.6 \mathrm{~Hz}, 2 \mathrm{H}$, aryl p-H).

${ }^{13} \mathrm{C}\left\{{ }^{1} \mathrm{H}\right\}$ NMR $\left(\mathrm{CDCl}_{3}, T=298 \mathrm{~K}, \mathrm{ppm}\right) \delta: 18.9\left(\mathrm{CH}_{3}, \mathrm{Ar}-\mathrm{CH}_{3}\right)$, $52.3\left(\mathrm{CH}_{3}, \mathrm{OCH}_{3}\right), 52.8\left(\mathrm{CH}_{3}, \mathrm{OCH}_{3}\right), 53.0\left(\mathrm{CH}_{3}, \mathrm{OCH}_{3}\right), 53.8\left(\mathrm{CH}_{3}\right.$, $\left.\mathrm{OCH}_{3}\right), 105.0(\mathrm{C}, \mathrm{C}=\mathrm{C}-\mathrm{I}), 125.1(\mathrm{C}$, aryl $\mathrm{i}-\mathrm{C}), 128.1(\mathrm{CH}$, aryl $\mathrm{m}-\mathrm{C})$, $130.6(\mathrm{CH}$, aryl p-C), $136.7(\mathrm{C}, \mathrm{C}=\mathrm{C}), 136.5$ (C, aryl o-C), $136.8(\mathrm{C}, \mathrm{CN})$, 142.4 (C, C=C), 160.2 (C, CO), 163.7 (C, CO), 166.3 (C, CO), 167.2 (C, $\mathrm{C}=\mathrm{C}), 171.1(\mathrm{C}, \mathrm{CO})$.

IR (KBr pellets, $\left.\mathrm{cm}^{-1}\right): \nu_{\mathrm{C}-\mathrm{O}} 1204, \nu_{\mathrm{C}}={ }_{\mathrm{O}} 1697, \nu_{\mathrm{C}} \equiv_{\mathrm{N}} 2197$.

Anal. Calc. for: $\mathrm{C}_{30} \mathrm{H}_{30} \mathrm{I}_{2} \mathrm{~N}_{2} \mathrm{O}_{8} \mathrm{Pd}$ : C, 39.74; H, 3.33; N, 3.09. Found: C, 39.91; H, 3.27; N, 2.94\%.

\section{Synthesis of complex $\mathbf{3 b}$}

The title complex was synthesized following a similar procedure as complex 3a using the derivative $\mathbf{1 b}$ as starting complex.

Orange microcrystals. Yield 63\%.

${ }^{1} \mathrm{H}$ NMR (acetone- $\left.\mathrm{d}_{6}, T=298 \mathrm{~K}, \mathrm{ppm}\right) \delta: 2.51\left(\mathrm{~s}, 6 \mathrm{H}\right.$, aryl- $\left.\mathrm{CH}_{3}\right)$, $3.57\left(\mathrm{~s}, 3 \mathrm{H}, \mathrm{OCH}_{3}\right), 3.68\left(\mathrm{~s}, 3 \mathrm{H}, \mathrm{OCH}_{3}\right), 3.72\left(\mathrm{~s}, 3 \mathrm{H}, \mathrm{OCH}_{3}\right), 3.78(\mathrm{~s}, 3 \mathrm{H}$, $\left.\mathrm{OCH}_{3}\right) 5.67\left(\mathrm{~s}, 4 \mathrm{H}, \mathrm{CH}_{2} \mathrm{SO}_{2}\right), 7.55\left(\mathrm{~d}, J=8.3 \mathrm{~Hz}\right.$, aryl $\left.\mathrm{H}_{3}\right), 7.85$ (d, $J=8.3 \mathrm{~Hz}$, aryl $\left.\mathrm{H}^{2}\right)$.

${ }^{13} \mathrm{C}\left\{{ }^{1} \mathrm{H}\right\}$ NMR, not available owing to the fast decomposition of the complex in solution.

IR (KBr pellets, $\left.\mathrm{cm}^{-1}\right): \nu_{\mathrm{C}-\mathrm{O}} 1155, \nu_{\mathrm{C}}=\mathrm{O}_{\mathrm{O}} 1718, \nu_{\mathrm{C}} \equiv_{\mathrm{N}} 2225$.

Anal. Calc. for: $\mathrm{C}_{30} \mathrm{H}_{30} \mathrm{I}_{2} \mathrm{~N}_{2} \mathrm{O}_{12} \mathrm{PdS}_{2}$ : C, 34.82; $\mathrm{H}, 2.92 ; \mathrm{N}, 2.71$. Found: C, 34.97; H, 3.12; N, 2.89\%.

\section{Synthesis of complex $3 c$}

The title complex was synthesized following a similar procedure as complex 3a using the derivative 1c as starting complex. The evaporation of $\mathrm{CH}_{2} \mathrm{Cl}_{2}$ was however complete and the resulting solid material was hence dissolved in diethyl ether and eventually precipitated with pentane.

Dark yellow microcrystals. Yield 78\%.

${ }^{1} \mathrm{H} \mathrm{NMR}\left(\mathrm{CDCl}_{3}, T=298 \mathrm{~K}, \mathrm{ppm}\right) \delta: 1.56\left(\mathrm{~s}, 18 \mathrm{H}, \mathrm{NC}\left(\mathrm{CH}_{3}\right)_{3}\right), 3.74$ $\left(\mathrm{s}, 3 \mathrm{H}, \mathrm{OCH}_{3}\right), 3.81\left(\mathrm{~s}, 3 \mathrm{H}, \mathrm{OCH}_{3}\right), 3.84\left(\mathrm{~s}, 3 \mathrm{H}, \mathrm{OCH}_{3}\right), 3.86(\mathrm{~s}, 3 \mathrm{H}$, $\left.\mathrm{OCH}_{3}\right)$.

${ }^{13} \mathrm{C}\left\{{ }^{1} \mathrm{H}\right\} \mathrm{NMR}\left(\mathrm{CDCl}_{3}, \mathrm{ppm}\right) \delta: 29.8\left(\mathrm{CH}_{3}, \mathrm{NC}\left(\mathrm{CH}_{3}\right)_{3}\right), 52.3\left(\mathrm{CH}_{3}\right.$, $\left.\mathrm{OCH}_{3}\right), 52.9\left(\mathrm{CH}_{3}, \mathrm{OCH}_{3}\right), 53.0\left(\mathrm{CH}_{3}, \mathrm{OCH}_{3}\right), 54.0\left(\mathrm{CH}_{3}, \mathrm{OCH}_{3}\right), 102.5$ $(\mathrm{C}, \mathrm{C}=\mathrm{C}-\mathrm{I}), 123.1(\mathrm{C}, \mathrm{CN}), 132.6(\mathrm{C}, \mathrm{C}=\mathrm{C}), 145.0(\mathrm{C}, \mathrm{C}=\mathrm{C}), 160.2(\mathrm{C}$, CO), 164.5 (C, CO), 165.4 (C, CO), 168.3 (C, C=C), 171.0 (C, CO).

IR ( $\mathrm{KBr}$ pellets, $\left.\mathrm{cm}^{-1}\right): \nu_{\mathrm{C}-\mathrm{O}} 1237, \nu_{\mathrm{C}}={ }_{\mathrm{O}} 1720, \nu_{\mathrm{C}} \equiv_{\mathrm{N}} 2219$.

Anal. Calc. for: $\mathrm{C}_{22} \mathrm{H}_{30} \mathrm{I}_{2} \mathrm{~N}_{2} \mathrm{O}_{8} \mathrm{Pd}$ : C, 32.59; H, 3.73; N, 3.46. Found: C, $32.41 ; \mathrm{H}, 3.85 ; \mathrm{N}, 3.33 \%$.

\section{Preliminary reactivity study and kinetic measurements}

The isomerization reaction was preliminarily investigated by ${ }^{1} \mathrm{H}$ NMR technique by mixing in a test tube almost equimolecular solutions of complex $\mathbf{1 a}$ and $\mathrm{I}_{2}\left([\mathbf{1} \mathbf{a}]_{0} \approx\left[\mathrm{I}_{2}\right]_{0} \approx 1 \times 10^{-2} \mathrm{~mol} \mathrm{dm}^{-3}\right)$ in $\mathrm{CDCl}_{3}$ at $298 \mathrm{~K}$ and following the reaction progress for at least $30 \mathrm{~m}$. The determination of the isomerization rate constant was carried out by a temperature controlled ( $298 \mathrm{~K}$ ) UV-vis experiment by adding to three $\mathrm{ml}$ of a solution of complex $\mathbf{1 a}$ in $\mathrm{CHCl}_{3}$ $\left([\mathbf{I} \mathbf{a}]_{0}=1 \times 10^{-4} \mathrm{~mol} \mathrm{dm}^{-3}\right)$ microaliquots of concentrated $\mathrm{CHCl}_{3}$ solutions of $\mathrm{I}_{2}$ into a quartz cell. The reaction was followed by either recording the absorbance change in the wavelengths range $300-400 \mathrm{~nm}$ or at fixed wavelength $(\lambda=340 \mathrm{~nm})$. The $\mathrm{I}_{2}$ concentration varied between $1 \times 10^{-3}$ and $2 \times 10^{-3} \mathrm{~mol} \mathrm{dm}^{-3}$ whereas $[\mathbf{1 a}]_{0}$ was held constant at $1 \times 10^{-4} \mathrm{~mol} \mathrm{dm}^{-3}$.

The reductive elimination of $I_{2}$ from the intermediate $I$ and the consequent formation of complex $\mathbf{2 a}$ was followed at fixed wavelength $(\lambda=340 \mathrm{~nm})$ by adding to the complex 1a $\left([\mathbf{1 a}]_{0}=1 \times 10^{-4} \mathrm{~mol} \mathrm{dm}^{-3}\right)$ microaliquots of a $\mathrm{CHCl}_{3}$ solution of $\mathrm{I}_{2}$ $\left(\left[\mathrm{I}_{2}\right]_{0}=1.06 \div 1.29 \times 10^{-4} \mathrm{~mol} \mathrm{dm}^{-3}\right)$ and following the absorbance change at $340 \mathrm{~nm}$ for ca. $60 \mathrm{~s}$.

\section{References}

[1] (a) Y. Wakatsuki, K. Aoki, H. Yamazaki, J. Am. Chem. Soc. 96 (1974) 5284-5285;

(b) Y. Wakatsuki, K. Aoki, H. Yamazaki, J. Am. Chem. Soc. 101 (1979) 1123-1130;

(c) B.M. Trost, A.F. Indolese, T.J.J. Müller, B. Treptow, J. Am. Chem. Soc. 117 (1995) 615-623;

(d) J. Le Paih, S. Dérien, I. Ozdemir, P.H. Dixneuf, J. Am. Chem. Soc. 122 (2000) 7400-7401;

(e) R. Morita, E. Shirakawa, T. Tsuchimoto, Y. Kawakami, Org. Biomol. Chem. 3 (2005) 1263-1268;

(f) E.-I. Negishi, G. Takahashi, S. Baba, D.E. van Horn, N. Okukado, J. Am. Chem. Soc. 109 (1987) 2393-2401;

(g) E. Shirakawa, G. Takahashi, T. Tsuchimoto, Y. Kawakami, Chem. Commun (2001) 2688-2689;

(h) F. Tellier, R. Sauvêtre, J.F. Normant, J. Organomet. Chem. 303 (1986) 309-315;

(i) J.K. Stille, B.L. Groh, J. Am. Chem. Soc. 109 (1987) 813-817;

(j) J.-H. Li, Y. Liang, Y.-X. Xie, J. Org. Chem. 69 (2004) 8125-8127;

(k) H. Hattori, M. Katsukawa, Y. Kobayashi, Tetrahedron Lett. 46 (2005) 5871-5875.

[2] G. Solladié, G.B. Stone, J.-M. Andrés, A. Urbano, Tetrahedron Lett. 34 (1993) 2835-2838.

[3] (a) E.S. Johnson, G.J. Balaich, P.E. Fanwick, I.P. Rothwell, J. Am. Chem. Soc. 119 (1997) 11086-11087;

(b) S. Yamaguchi, R.-Z. Jin, K. Tamao, F. Sato, J. Org. Chem. 63 (1998) 10060-10062;

(c) Y. Yamamoto, T. Ohno, K. Itoh, Chem. Commun. (1999) 1543-1544;

(d) J. Ryan, G.C. Micalizio, J. Am. Chem. Soc. 128 (2006) 2764-2765;

(e) S.L. Buckwald, R.B. Nielsen, J. Am. Chem. Soc. 111 (1989) 2870-2874;

(f) T. Takahashi, M. Kotora, K. Kasai, N. Suzuki, Organometallics 13 (1994) 4183-4185;

(g) T. Takahashi, Z. Xi, A. Yamazaki, Y. Liu, K. Nakajima, M. Kotora, J. Am. Chem. Soc. 120 (1998) 1672-1680; 
(h) J.M. O'Connor, K. Hiibner, R. Merwin, P.K. Gantzel, B.S. Fong, M. Adams, A.L. Rheingold, J. Am. Chem. Soc. 119 (1997) 3631-3632.

[4] (a) K. Mosely, P.M. Maitlis, Chem. Commun. (1971) 1604-1605;

(b) H. Suzuki, K. Itoh, Y. Ishii, K. Simon, J.A. Ibers, J. Am. Chem. Soc. 98 (1976) 8494-8500;

(c) R. van Belzen, H. Hoffman, C.J. Elsevier, Angew. Chem. Int. Ed. Engl. 36 (1997) 1743-1745;

(d) R. van Belzen, R.A. Klein, H. Kooijman, N. Veldman, A.L. Spek, C.J. Elsevier, Organometallics 17 (1998) 1812-1825;

(e) E. Shirakawa, H. Yoshida, Y. Nakao, T. Hiyama, J. Am. Chem. Soc. 121 (1999) 4290-4291;

(f) H. Yoshida, E. Shirakawa, Y. Nakao, Y. Honda, T. Hiyama, Bull. Chem. Soc. Jpn. 74 (2001) 637-647;

(g) R. van Belzen, C.J. Elsevier, A. Dedieu, N. Veldman, A.L. Spek, Organometallics 22 (2003) 722-736;

(h) L. Canovese, F. Visentin, G. Chessa, P. Uguagliati, C. Santo, L. Maini, J. Organomet. Chem. 692 (2007) 2342-2345;

(i) L. Canovese, F. Visentin, C. Santo, J. Organomet. Chem. 692 (2007) 4187-4192;

(j) L. Canovese, F. Visentin, C. Levi, C. Santo, J. Organomet. Chem. 693 (2008) 3324-3330.

[5] (a) L. Canovese, F. Visentin, G. Chessa, P. Uguagliati, C. Levi, A. Dolmella, Organometallics 24 (2005) 5537-5548;

(b) L. Canovese, F. Visentin, G. Chessa, P. Uguagliati, C. Levi, A. Dolmella, G. Bandoli, Organometallics 25 (2006) 5355-5365;

(c) A. Holuigue, J.M. Ernsting, F. Visentin, C. Levi, L. Canovese, C.J. Elsevier, Organometallics 27 (2008) 4050-4055.

[6] Remarkably, the initial absorbance strongly depends on the concentration of $\mathrm{I}_{2}$ whereas the calculated reaction rate is independent of such a concentration.
The observed absorbance change is probably due to the interaction between iodine and the aromatic systems of the isocyanide, such an interaction is a well known and described phenomenon that is widely documented in the literature [7].

[7] F.A. Cotton, G. Wilkinson, C.A. Murillo, M. Bochmann, in: Advanced Inorganic Chemistry, sixth ed., 1999, J. Wiley Ed., New York (Chapter 13).

[8] J.P. Perdew, K. Burke, M. Ernzerhof, Phys. Rev. Lett. 78 (1997) 1396.

[9] M. Steinmetz, S. Grimme, ChemistryOpen 2 (2013) 115-124.

[10] M.L. Tobe, J. Burgess, Inorganic Reaction Mechanism, Addison Wesley, New York, 1999.

[11] W.L.F. Almarengo, D.D. Perrin, Purification of Laboratory Chemicals, third ed., Pergamon, New York, 1988.

[12] M.J. Frisch, G.W. Trucks, H.B. Schlegel, G.E. Scuseria, M.A. Robb, J.R. Cheeseman, G. Scalmani, V. Barone, B. Mennucci, G.A. Petersson, H. Nakatsuji, M. Caricato, X. Li, H.P. Hratchian, A.F. Izmaylov, J. Bloino, G. Zheng, J.L. Sonnenberg, M. Hada, M. Ehara, K. Toyota, R. Fukuda, J. Hasegawa, M. Ishida, T. Nakajima, Y. Honda, O. Kitao, H. Nakai, T. Vreven, J.A. Montgomery Jr., J.E. Peralta, F. Ogliaro, M. Bearpark, J.J. Heyd, E. Brothers, K.N. Kudin, V.N. Staroverov, R. Kobayashi, J. Normand, K. Raghavachari, A. Rendell, J.C. Burant, S.S. Iyengar, J. Tomasi, M. Cossi, N. Rega, J.M. Millam, M. Klene, J.E. Knox, J.B. Cross, V. Bakken, C. Adamo, J. Jaramillo, R. Gomperts, R.E. Stratmann, O. Yazyev, A.J. Austin, R. Cammi, C. Pomelli, J.W. Ochterski, R.L. Martin, K. Morokuma, V.G. Zakrzewski, G.A. Voth, P. Salvador, J.J. Dannenberg, S. Dapprich, A.D. Daniels, Ö. Farkas, J.B. Foresman, J.V. Ortiz, J. Cioslowski, D.J. Fox, Gaussian 09, Gaussian, Inc., Wallingford, CT, 2009.

[13] F. Weigend, R. Ahlrichs, Phys. Chem. Chem. Phys. 7 (2005) 3297-3305.

[14] (a) V. Barone, M. Cossi, J. Phys. Chem. A 102 (1998) 1995-2001;

(b) M. Cossi, N. Rega, G. Scalmani, V. Barone, J. Comput. Chem. 24 (2003) 669-681. 